\title{
AN IMPLEMENTATION PROPOSAL OF INNOVATIVE PRICING IN GREEK COASTAL SHIPPING
}

\author{
loannis SITZIMIS \\ Department of business administration \& Tourism, Hellenic Mediterranean University, \\ Heraklion, Greece \\ isitzimis@hmu.gr
}

\begin{abstract}
Greek coastal shipping is an industry which passed from the state regulatory interference to market forces. Its fare structure (tariff) was based on average (or total) cost and distance was the representative cost variable. As it is an industry facing strong economies of scale, average cost is higher than marginal cost. This means that companies equalizing prices to marginal cost, following Pareto-efficient allocation of resources, are driven to losses and are forced to seek other methods of efficient pricing policy. The purpose of this article is to examine the implementation of "innovative" pricing in Greek coastal shipping. "Innovative" pricing contains applicable measures in order to increase ticket prices in "peak" periods without affecting the level of quality, the number of passengers and the market share. The analysis results show that average fare will not necessarily raise. Ticket increases may be accompanied by quantitative discounts in periods of low demand. In these cases, "season tickets" can be applied.
\end{abstract}

Keywords: Greek coastal shipping, peak periods, economies of scale, innovative pricing, season tickets

JEL Classification: R40, M21

\section{Introduction}

Greek coastal shipping (GCS), especially after 1976 (Presidential Decree 684/1976), was subjected to government regulation. The state used to decide the level of fares and give an operating license per vessel and per route. It never defined the quality of the supplied service, as it was supposed to and as the rest countries of European Union and Unites States of America, did. The supply of coastal services was based on political criteria. The demand could not be regulated and it was mainly based on domestic and foreign tourism. Later, the situation changed. Greece had to comply, until 01/01/2004, with the European regulation 3577/92 on the abolition of the existing cabotage privilege of ships bearing its flag. Actually, "cabotage" was the institutional right of ships bearing the Greek flag above 1.000 gross register tonnage (GRT) to proceed to coastal shipping. This was a common situation for most European countries (of Southern Europe) that were members of European Union. According to Greek Law 2932/2001, which was launched in November 2002, the state attempted the "deregulation" of the Greek coastal system. This fact enabled coastal companies to set the fares they wish and submit once a year a draft of the routes they want to serve (based on their business strategy). In practice, the lifting of cabotage privilege on the one hand marked the beginning of gradual removal of entry barriers, and on the other

Cite as:

Sitzimis, I., 2021. An Implementation Proposal of Innovative Pricing in Greek Coastal Shipping. Oradea Journal of Business and Economics, 6(2), pp. 69-77. http://doi.org/10.47535/19910jbe130 
introduced the rules of free competition to ensure the appropriate conditions of a full and deregulated market (Goulielmos and Sitzimis, 2014). Actually, there was a long transition from a regulated regime to market forces (lasted 12 years). Only security remained in state hands. The liberalization of coastal market, which was initiated in 2002 and was completed in 2006, led to major changes in fares and pricing policies of Greek coastal companies Unexpectedly, the average fares of conventional vessels raised by $49 \%$ and of high speed vessels by $21.5 \%$ (were already high). The main reasons were on the one hand the rising fuel prices and on the other that fares (until 2006) were very low (almost $40 \%$ lower than the rest countries of European Union) (Goulielmos and Sitzimis, 2014).

The European coastal industry and air transport offer useful conclusions about the impacts of liberalization to a transportation industry (Holloway, 2006; Wilfred, 2006; Forsyth, 1997; Sitzimis, 2012; Arvanitis and Papatheodorou, 2015). We could be based on them and draw the appropriate conclusions for GCS, especially in relation to pricing policy. However, these industries are characterized by different market conditions. Their research results cannot be fully adapted to GCS (Goulielmos and Sambrakos, 2002). This market consists of several concentrated submarkets-coastal routes, which should be analyzed individually (Besanko, et al., 2010; Sitzimis, 2021). Actually, most of Greek coastal itineraries are monopolistic, duopolistic or oligopolistic (Goulielmos and Sitzimis, 2012). Typical examples are the coastal routes "Piraeus-Rethimnon", "Piraeus-Kissamos" (monopolistic), "Piraeus-Kos", "PiraeusMytilini", Piraeus-Chania", "Piraeus-Heraklion", "Piraeus-Chios" (duopolistic) and "PiraeusMykonos", "Piraeus-Amorgos", "Piraeus-Santorini" (oligopolistic) (in some of the above routes there are strategic alliances between companies in order to serve the capacity demand together and reduce their cost). We prefer a realistic and rational analysis of GCS, as formed after the lifting of cabotage privilege, by analyzing the impacts of liberalization in pricing strategy per coastal route. Therefore, our suggestions do not aim to cover the entire market but each coastal line separately.

Pricing in GCS has always been difficult. There was an asymmetry of information between Ministry of maritime affairs and insular policy (MMAIP), which determined the fares and coastal business owners which received the fares (Lekakou and Fafaliou, 2003). GCS tried to establish a fare structure (tariff) based on cost and especially the average (or total) cost to receive back what is spent on each trip, plus a reasonable profit (Goulielmos, 1998). MMAIP in order to protect itself from any criticism chose the cost per mile and thus the fare per mile. The distance, according to transport economics theory (Gwilliam and Mackie, 2017), was the representative variable of cost. By this way the intensity of demand, competition and quality was ignored (Goulielmos and Sambrakos, 2002).

GCS, under the rule of distance, claimed fares per mile which were determined by the political pressure of the coastal business owners. Ticket price increases were based on MMAIP decisions as a percentage increase. However, there were differences in passenger and vehicle fares. Prices were never uniform, as they often did not coincide even at the same distances (Goulielmos and Sambrakos, 2002). This is proved by the frequent deviation from the liner model of the fare per mile and per distance (Sitzimis, 2012; Goulielmos, 2004; Goulielmos and Sambrakos, 2002).

Nevertheless, there are reasonable pricing theories, when strong economies of scale exist in an industry. In these cases, marginal cost (MC) is below the average cost (AC) and fixed cost (FC) is high (Train, 1994). The fact that GCS is an industry of strong economies of scale has been demonstrated, and we'll take that for granted (Centre of planning and economic research - CPER), 1992; Goulielmos and Sitzimis, 2014; Sitzimis, 2021; Goulielmos and Gatzoli, 2008). In addition, there are economies of scale in all kinds of vessels (e.g. tankers, container ships) (Ma, 2020).

The purpose of this article is to examine the implementation of "innovative" pricing and "season tickets" in GCS. We think that it is an interesting approach since no other researcher has suggested anything similar for this industry so far. The main research question here is 
which is the most efficient pricing in GCS, a shipping industry which passed from the state regulatory interference, partly in the beginning and fully later, to market forces. Its contribution is based on pricing analysis of Greek coastal market per route and the proposition of "innovative" pricing as the best in GCS.

\section{Peak periods and economies of scale}

As it is known, a necessary condition for Pareto-efficient allocation of resources is the equation of prices $(P)$ and marginal costs $(P=M C)$ (Varian, 2019). It is a first-best pricing policy. However, as Quinet (2005) states for transport industry, "in the first-best world there are no external effects, no public goods, firms are price-takers, there is no tax or taxes are optimal, there is no uncertainty or asymmetry in information and there are no transaction costs and no redistribution issues". In transport sector, these conditions are non-existent and unrealistic and usually the pricing result is second-best. This means that pricing changes do not make one user better off without making at least one user worse off. If ticket prices cannot be set equal to MC due to constraints within the transport industry or other economy distortions, these policies are considered for (Maffii, Parolin and Ponti, 2010).

In GCS the first-best fare, theoretically, is related to social welfare maximization. It could be defined as the sum of user and coastal operator benefits (Tirachini and Hensher, 2012). Two issues deserve special mention in relation with pricing based on MC. The first one is the problems experienced at peak times (if the size of the ship is not big enough) such as holidays and summer months. The marginal costs in these periods are very high, as high demand potentially requires investment in increased capacity (Rungaar, 2000). These costs must be distributed to a number of passengers who travel during peak periods (when coastal routes show high occupancy rates). The second one is the existence of economies of scale. Regarding the problem of peak times, the marginal costs are relatively fixed and low as the number of passengers is smaller than the available capacity (Verhoef et al, 2008). In the short run, there is no possibility for an increase in supply capacity (only an augmentation in itineraries if $100 \%$ of occupancy has been achieved) in order to meet the growing peak demand. So, the short run MC increases. The same applies to the marginal social cost as a result of redundant passengers and crowded vessels and ports (Mathisen, 2008). In nonpeak periods MC from an additional passenger, vehicle or private car will increase slightly or not at all (there are aspects of fixed MC until the maximum utilization of the ship is reached), unless there is an increase in speed or routes or fuel costs. In the long run, there could be an adjustment to increased capacity demand by new investments (number or vessel size), without sharp increases in long-term MC (Cole, 2006). There is always the assumption that MC is higher in peak periods (Rantzien and Rude, 2014). The reason is that the coastal fleet and staff cannot be used effectively to serve the peak periods, in contrast to periods of low demand. So, passengers who travel at periods of "high" demand could be charged more than others because of increasing MC.

In relation to the second point, namely the economies of scale, it is necessary to specify that "efficient" pricing means MC pricing (Fearnley, 2003). In GCS there are high fixed costs, estimated at around 70\% of total cost (TC)1 (CPER, 1992; Goulielmos and Sambrakos, 2002; Sitzimis, 2021; Foundation for economic and industrial research (FEIR), 2021). According to economic theory if $\mathrm{MC}<\mathrm{AC}$ and $\mathrm{FC}$ is high there are strong economies of scales

\footnotetext{
1 In GCS FC is related to crew costs (41.5\%), repairs, maintenance and stores (14.4\%), insurance $(3.5 \%)$ and administration cost-general expenses (8.8\%) (totally $68.2 \%)$. The other $31.8 \%$ is variable (voyage) cost and includes fuel and lubricants (22\%) and port expenses (9.8\%) (data of 1992). Nowadays, the situation has remained the same. In the year 2016 and for three of the largest companies in the industry (Blue Star Ferries, Anek Lines, Hellenic Seaways) FC is estimated at $70.2 \%$ and VC at $29.8 \%$.
} 
and revenues do not cover operating costs (Oustabasidis and Katsoulakos, 1999). If we define MC as the cost of an extra coastal voyage then it is equal to voyage's VC. This means that there is huge deviation between FC and MC in GCS. So companies are driven to losses and are forced to seek other methods of efficient pricing policy (Sitzimis, 2021).

For the effective implementation of an efficient pricing policy in peak periods, passengers should realize that each trip is associated with an operating cost. They must understand that they are required to pay more, and should contribute significantly to this higher MC (Rantzien and Rude, 2014). The "peak" pricing fits in this case. A uniform price in peak periods offers no benefits to either companies or passengers (Larsen, 1998; Rantzien and Rude, 2014). Companies face very high marginal costs and passengers overcrowding and lack of service. Therefore, the prices must be increased in these periods and must be decreased in others (Borge, et al., 1996). By this way, the average annual price could be lower. The fare structure will then reflect the marginal costs and will allocate increases in capacity demand.

Discounts in periods of low demand constitute the most classical method to differentiate fares (Cole, 2006; Holloway, 2006). This will lead passengers who travel in peak periods (excluding those traveling for vacation or business) to periods of excess capacity and will attract new passengers (generally it will attract those who charge the system less) (Fearnley, 2003). In the short run, however, the total revenues of coastal companies will not be increased. Neither the average fare will change. Also, there is "room" for increases in tickets in high demand periods. Of course, even if many travelers of peak periods, have a low-price elasticity of demand (Borenstein and Rose, 1994; Sitzimis, 2012; Hanly and Dargay, 1999) some of them will react to price increases and will modify their behavior (Henn, et al., 2010). Although, if we assume that in some routes there is no alternative transport option (arrival/ departure time, lack of competitors) revenues from the tickets will grow reasonably. For instance, in coastal route "Piraeus-Rethimnon" where there is not an airport and there is only one coastal company (Sea Speed Ferries). The same could happen if the quality of passenger vessel is great (speed, comfort of living spaces, staff service). The high-speed vessel "Elyros" (belongs to the company Anek Lines) which is routed on the coastal line "Piraeus-Chania" received the award for best ship conversion on European area in 2008 (shippax award 2008). Its quality is a given and possibly exceeds the expensive fare.

\section{Implementation proposal and methodology}

As far as the state subsidies are less than an optimal amount, or cut, coastal business owners will increasingly depend on passenger fares (plus personal vehicles and trucks fares), to finance their business operation, because the equation $M R=M C$ with $M C<A C$ is resulting in losses (Goulielmos and Sitzimis, 2012; Sitzimis, 2021). The controversial matter is how can ticket prices increase and simultaneously remain unchanged: (1) the level of quality, (2) the number of passengers and (3) the market share.

We propose here the use of "innovative" pricing. The objectives of innovative pricing is the effective reimbursement of costs without loss of demand and market share (Fearnley, 2003). It is a strategy to improve the efficiency of pricing in order to minimize the loss of prosperity. The basic principle is, as it is well known, that fares should reflect variations in marginal costs at different times of day and different routes (Cole, 2006). Also, fares should be dependent on the price elasticity of demand for different categories of passengers (Cowie and Ison, 2017). "Innovative" pricing introduces different prices to different user groups (passengers). Passengers who do not have high price sensitivity (inelastic demand), should pay, according to theory, more (Varian, 2019). This pricing strategy is second best, diminishes the loss of wealth (Proost and Dender, 2003) and helps Greek coastal owners to maximize profits (Nagle and Holden, 2001). The most familiar form of "innovative" pricing is the diversification of fares according to the reporting period (e.g. peak pricing) (Goulielmos and Gatzoli, 2008). 
If coastal business owners want to cover their costs by setting uniform prices, then prices should be equated with AC. But this is not a perfect choice (Goulielmos, 2004) and used to happen in GCS before deregulation (Spathi, 2005). Prices should be equated to MC. But the pricing based on $\mathrm{MC}$ will lead to losses (because $M C<A C$ ) and it is not appropriate, as I have already mentioned (Cole, 2006). The existence of economies of scale is a characteristic of capital-intensive industries (such as GCS) and the above result is expected. Passengers may consider that uniform prices are fairer than the discriminated ones (Cole, 2006). Although, in the context of economic efficiency, and where subsidies are lower than the best, the uniformity of prices does not constitute a desirable strategy (Holloway, 2006). The uniform prices encourage coastal companies to focus on passengers with the willingness or ability to pay the fare (Schwieterman, 1985; Gwilliam and Mackie, 2017). That way prices are "pushed" upwards. In other words, price discrimination is not just a tool to maximize profit, but also a tool to achieve satisfactory services and maybe satisfied passengers (Geradin and Petit, 2005). The main difference of uniform pricing and peak pricing is that the first is based on the price elasticity of demand (of passengers) and the second to changes in costs (Cowie and Ison, 2017). It is worth mentioning that price discrimination leads to waste of resources when the total offered capacity is reduced compared to the capacity offered when there is a use of uniform price (Geradin and Petit, 2005). Therefore, a necessary but not sufficient condition for the acquisition of wealth, is when production increases through price discrimination (Mcafee, 2008; Fearnley, 2003).

In GCS, one option is to charge a participation "fee" to access the coastal service along with the ticket price which is equalized to MC. This "fee" will be the same regardless if the passenger makes one or more trips annually. It will not change the (marginal) options of passengers, namely if they make or not an extra trip. This is an efficient pricing. The "fee" should cover the fixed cost of transport. This means that the deviance between AC and MC of transport, will not lead the company to losses.

According to Fearnley's theory (2003), the total ticket price (P) be paid by the passenger for a given period could be:

$$
P=F+T \times X
$$

Where:

$\mathrm{F}$ : The participation fee in the given period.

$\mathrm{T}$ : The price which is equalized to MC.

$\mathrm{X}$ : The number of trips.

In this pricing structure of fares, passengers will have "quantitative" discounts. As many trips a person makes annually, the lower the level of fares will be. When a trip takes place, the passenger will pay $F+T$. When the number of trips tends to infinity (theoretically), the average ticket price will be closer to $\mathrm{T}$, namely a price equalized to $\mathrm{MC}$. It is, in our view, a simple pricing for both coastal business owners and for GCS passengers. Occasional passengers must not be discouraged from using the transport service due to a potential high "fee". The sum F + T should not affect the price elasticity of demand.

Persistent research on this issue led us to Fearnley's theory (he supported the "inventive" pricing of urban public transport). The pricing policy described above, is successfully applied in telecommunications, electricity, water supply network and sewage network too (Fearnley, 2003).

\section{Season tickets and results}


The occupancy rate of Greek coastal companies is quite low during the winter months (Goulielmos and Sambrakos, 2002; Lekakou and Fafaliou, 2003; Sitzimis, 2012). At the same time, fares can be increased only at periods of high demand. We believe that a combination of "innovative" pricing and "season tickets" (ST) (weekly, monthly) could on the one hand increase the capacity of current demand throughout the year and on the other decrease the average fare.

If a pricing policy aims at connecting the level of fares to the actual AC, ST are not consistent with MC pricing (Fearnley, 2003). Their holder does not understand that an additional trip has a cost (unless passenger "lose" time and comfort) and maybe lead to increasing and pointless use of ferry transportation (more itineraries with low occupancy rates). It's clear that ST will be particularly attractive to those users who travel for business matters. Indeed, a part of the design provision of the offered capacity is based on them. This leads to a situation where the more "regular" passengers, traveling with ST (at peak periods), paying zero marginal fare. Such pricing would create excessive capacity demand in periods where the costs are high. By this way, the issue of ST, without restrictions, does not lead to Pareto efficient pricing.

However, this analysis does not mean that this proposal is wrong. Passengers traveling in non-peak periods in low demand routes impose nearly zero MC. Therefore, in these cases, ST are applicable. In GCS, because of seasonality, months April to September account for $70 \%$ of passenger traffic (FEIR, 2021; Sitzimis, 2021). In these "peak" months, when MC is high, fares should be raised. For the remaining months (November to March) the fall of ticket prices is indicated. This can happen through the purchase of ST (quantitative discounts). Particularly, in relation to ST, the more coastal itineraries take place (according to "innovative" pricing and instead of buying a one-way ticket) the more the average fare decrease and approach MC. The final result could be a reduction in the average fares of passengers.

In our opinion, the advantages of the above pricing policy are many. Coastal passengers will realize that the transfer involves costs which vary between peak periods and not. Some passengers will change the day of travel, creating lower operational costs of transport (it is difficult but not impossible for GCS). Discounts (ST or/and offers) in non-peak periods will increase the number of passengers and will reduce the average fare. It will not change the level of coastal services, but will provide increased mobility to less affluent travelers. Also, "peak" passengers will increase operating revenues, as they charged more.

\section{Conclusions}

The European regulation 3577/1992 and Greek Law 2932/2001 led to "cabotage waiving" of Greek coastal system. GCS abandoned entry restrictions and price determination of the state after a 12-year long transition period (partly in 2002 and fully in 2006). In relation to pricing policy and due to economies of scale existence, Greek ship-owners tend to set prices which cover all operating costs. This is not socially acceptable as does not meet the condition for Pareto - efficient allocation of resources. Unfortunately, in GCS a pricing method based on AC lead to losses, as AC is lower than MC.

The "innovative pricing" was proposed for implementation in GCS. It contains applicable measures to increase revenues while maintaining (or increasing) the quality level of the companies of GCS. The price in this case minimizes the loss of wealth, raises user's income and reflects the structures of cost and demand. Different passengers pay a different fare based on the characteristics of demand and operating costs of the services. The key point is the charge of a participation "fee" which covers the fixed cost of transport. If price discrimination is determined, the average fare will not necessarily raise. Increases in peak periods may be accompanied by price reductions (or discounts) in periods of low demand. 
A uniform price structure is not optimal from a social standpoint, as it does not take into account the MC and demand. The uniform fares tend to be higher than fares based on MC. Passengers who are willing to pay more than the marginal operating costs and less than the actual fare, are discouraged to travel. This causes a loss of income and revenue. Passengers traveling in non-peak periods, or in routes of low demand, impose nearly zero MC. In these cases, ST can be applied.

\section{References}

Arvanitis, P. and Papatheodorou, A., 2015. Greek Airports in Transition: From Public Ownership to PPP Concessions. Journal of Airport Management, 9(3), pp. 284-295.

Besanko, D., Dranove, D., Schaefer, S. and Shanley, M., 2010. Economics of Strategy. International Student Version, 5th ed., New Jersey: John Wiley \& Sons, Inc.

Borenstein, S. Rose, N., 1994. Competition and price dispersion in the U.S. airline industry. Journal of political economy, 102(4), pp. 653-683. https://doi.org/10.1086/261950

Borge, B., Mayeres, I., Proost, S. and Wouters, S., 1996. Optimal pricing of urban passenger transport. A simulation exercise of Belgium. Journal of transport economics and policy, XXX(1), pp. 31-54.

Cole, S., 2006. Applied transport economics. Policy, management and decision making, 3rd ed., London: Kogan page.

Cowie, J. Ison, S., 2017. The Routledge Handbook of Transport Economics., $1^{\text {st }}$ ed. Abingdon: Routledge.

CPER, 1992. Greek coastal shipping: analysis of financial operating conditions. Athens: Centre of planning and economic research.

Fearnley, N., 2003. Inventive pricing of urban public transport, TOI report 655/2003, Institute of transport economics, Oslo.

FEIR, 2021. Passenger shipping in Greece in 2016-2020: Performance, economic contribution and prospects, Athens: Foundation for economic and industrial research.

Forsyth, P., 1997. The gains from the liberalization of air trasport. A review of reform. Journal of transport economics and policy, 32(1), pp. 73-92.

Geradin, D. Petit, N., 2005. Price discrimination under EC competition law. The need for a case-by-case approach., GCLC Working Paper 07/05, the global competition law centre working papers series, College of Europe.

Goulielmos, A., 1998. Greek coastal passenger shipping in front of liberalization. Journal of transport economics, XXV(1), pp. 69-88.

Goulielmos, A., 2004. Management of coastal and maritime industries. Developments and changes since 1997, Peiraeus: Stamoulis.

Goulielmos, A. Gatzoli, A., 2008. The Structure of the Market in the Greek-Italian Sea Transportation: a theoretical and empirical investigation. International journal of ocean systems management, 1(2), pp. 169-187. https://doi.org/10.1504/IJOSM.2009.030183 Goulielmos, A. Sambrakos, E., 2002. Coastal and short sea shipping, Peiraeus: Stamoulis. Goulielmos, A. Sitzimis, I., 2012. Measuring market concentration in the Aegean Ferry System. Spoudai Journal, 62(1-2), pp. 7-27.

Goulielmos, A. Sitzimis, I., 2014. The Liberalization process of the Ferry System in Greece, 2001-2009: What have been the benefits to users of Aegean Sea Transportation?. Spoudai Journal, 64(4), pp. 39-66.

Gwilliam, K. Mackie, P., 2017. Economics and transport policy. 1st edition ed. London: Routledge.

Hanly, M., Dargay, J., 1999. Bus fare elasticities. A literature review, London: University college. 
Henn, L., Karpouzis, G. and Sloan, K., 2010. 'A review of policies and ecnonomic instruments for peak demand management in commuter rail', ATRF 2010: 33rd Australasian transport research forum.

Holloway, S., 2006. Straight and level: Practical airline economics. 2nd ed. Aldershot: Ashgate publishing Ltd.

Larsen, O., 1998. Elements in an optimum transport policy, TOI report 408/1998, Institute of transport economics, Oslo.

Lekakou, M. Fafaliou, I., 2003. The historical course of the Greek coastal transport services in the twentieth century and associated policy responses, Archives of economic history, $\mathrm{XV}(1)$, pp. 127-153.

Ma, S., 2020. Economics of Maritime Business. 1st ed., London: Routledge Maritime Masters.

Maffi, S., Parolin, R. and Ponti, M., 2010. Social marginal cost pricing and second best alternatives in partnerships for transport infrastructures. Research in transportation economics, 30, pp. 23-28. https://doi.org/10.1016/j.retrec.2010.10.004

Mathisen, T., 2008. Marginal Cost and Capacity Utilization: Calculating Short-run, Mediumterm, and Long-run Marginal costs in the Ferry Industry. Journal of transport economics and policy, XXXV(3), pp. 373-389.

Mcafee, P., 2008. Price discrimination. Issues in competition law and policy. American bar association section of antitrust law 465, pp. 465-484.

Nagle, T. Holden, R., 2001. The strategy and tactics of pricing. A guide to profitable decision making, 3rd ed., New Jersey: Prentice-Hall marketing series.

Oustabasidis, K. Katsoulakos, I., 1999. Applied industrial economics and policy. Thessaloniki: Zygos.

Proost, S. \& Dender, K., 2003. 'Marginal social cost pricing for all transport modes and the effects of modal budgets constraints', ETE working paper series 2003, No 2003-11, Open access publications from Katholieke universiteit Leuven.

Quinet, E., 2005. Alternative pricing doctrines, Research in transportation economics, 14, pp. 19-47. https://doi.org/10.1016/S0739-8859(05)14002-5

Rantzien, V. Rude, A., 2014. Peak-load pricing in public transport: a case study of Stockholm. Journal of transport literature, 8(1), pp. 52-94. https://doi.org/10.1590/S223810312014000100004

Rungaar, H., 2000. Efficient pricing in transport. The gap between theory and practice. European journal of transport and infrastracture research, 1(1), pp. 29-44.

Schwieterman, J., 1985. Fair is fair in airline deregulation. The decline of price discrimination. Regulation, Volume 9, pp. 32-38.

Sitzimis, I., 2012. Aegean coastal market: the consequences of cabotage removal by microeconomic tools, Phd thesis, Piraeus: University of Piraeus.

Sitzimis, I., 2021. An optimal forecasting method of passenger traffic in Greek coastal shipping. Under review in International Journal of Business and Economic Sciences Applied Research (IJBESAR).

Sitzimis, I., 2021. Economies of scale in Greek coastal shipping. Under review in European Transport/Transporti Europei.

Spathi, S., 2005. A comparison between air and coastal services in internal routes: An econometric estimation of demand, Athens: Center of programming and economical research.

Tirachini, A. Henser, D., 2012. Multimodal transport pricing: first best, second best and extensions to non-motorized transport. Transport reviews, 32(2), pp. 181-202. https://doi.org/10.1080/01441647.2011.635318

Train, K., 1994. Optimal regulation: the economic theory of natural monopoly, Cambridge: The MIT press.

Varian, H., 2019. Microeconomic analysis. 3rd ed., New York: W. W. Norton \& Company. 
Verhoef, E. T., Lindsey, C. R., Niskanen, E., de Palma, A., Moilanen, S., Proost, S. and Vold, A., 2008. Road pricing, the economy and the environment. Jensen-Butler, C., Sloth, B., Larsen, M. M., Madsen, B. \& Nielsen, O. A. (eds.). Berlin: Springer.

Wilfred, S., 2006. Airline Liberalization Effects on Fare: The Case of the Philippines. Journal of business research, 60(2), pp. 161-167. https://doi.org/10.1016/j.jbusres.2006.10.019

\section{Bio-note}

Sitzimis loannis (Phd) is teaching staff at the department of business administration \& tourism, at Hellenic Mediterranean University (HMU), located at Heraklion in Greece. As a researcher, Ioannis Sitzimis, focused on areas of transport economics and education economics and published several articles in this field. His main research interest is maritime sector, specializing in passenger shipping. 